\title{
Systemic Supplement with Resveratrol Increased Bone Formation in Rats' Alveolar Socket
}

\author{
Aumento de la Formación Ósea en el Hueso Alveolar de Rata \\ con Suplemento Sistémico con Resveratrol
}

\author{
Dariush Hasheminia ${ }^{\text {; }}$ Sayed Mohammad Razavi² Hamed Nazari'; \\ Saber Khazaei ${ }^{3}$; Pardis Soleimanzadeh ${ }^{4} \&$ Hesamedin Nazari $^{5}$
}

HASHEMINIA, D.; RAZAVI, S. M.; NAZARI, H.; KHAZAEI, S.; SOLEIMANZADEH, P. \& NAZARI, H. Systemic supplement with resveratrol increased bone formation in rats' alveolar socket. Int. J. Morphol., 36(2):391-394, 2018.

SUMMARY: Resveratrol in cell culture media increases osteoblastic markers. Also results from previous studies provide evidence for resveratrol positive effects on bone healing and bone production. In this preclinical study we investigated bone healing in rats by resveratrol systemic application. 30 Wistar male rats were divided into two groups (study group and control group). At first, maxillary second molars of rats were extracted. The rats were kept in laboratory for next 28 days. Study group received resveratrol $20 \mathrm{mg} / \mathrm{kg}$ by abdominal injection every day. The control group received placebo in the same manner that study group. Rats were sacrificed after 28 days and bone samples were collected from center of maxillary second molar socket. Samples were evaluated histologically for new bone formation, inflammation, necrosis, fibrosis and foreign body reaction. The mean difference of new bone formation in control group $(28.30 \%)$ and study group $(45 \%)$ were statistically significant $(\mathrm{P}=0.014)$. There were no significant differences in inflammation, fibrosis, necrosis and foreign body reaction $(\mathrm{P}>0.05)$. Resveratrol has positive effects on bone healing but more evidence needed from more clinical and animal studies.

KEY WORDS: Resveratrol; Alveolar ridge augmentation; Bone formation; Osteoblast; Osteoclast.

\section{INTRODUCTION}

The aesthetic and functional reconstruction of hereditary degenerative disorders, cleft palate, bone defects resulted from pathological or traumatic incidents, and sport related injuries have been subject of many clinical and laboratory studies. In past 30 years, vast information on bone reconstruction mechanism has been provided (Singh et al., 2000; Liu et al., 2005).

Different techniques and materials were used as regenerative materials for bone reconstruction. Biologic material like autologous, homologous or heterologous transplants, combination substitute materials and alloplastic material such as Hydroxyapatite or Polyethylen have been under examination through several studies (Pang et al., 2004; Zhou et al., 2009). Although there is current research on finding appropriate substitute material for destructed bone, but it seems the best method for reconstruction in bone defect continues to be, to induce bone to reconstruct itself. Consequently, several drugs have been used to accelerate and amplify ossification in bone regeneration (Casarin et al., 2014).

Resveratrol is a phytoalexin found in grapes, peanut and mulberries with various beneficial biological and pharmacological properties (Casati et al., 2013). It is reported that resveratrol can accelerate metabolic pathways and it has been shown that resveratrol has direct increasing effects on osteogenesis (Casarin et al.).

Resveratrol has been shown to increase osteoblastic differentiation gene expression. Also it has the ability to elevate alkaline phosphatase and Prolylhydroxylase levels dose dependency (Khazaei et al., 2012). Resveratrol can increase osteoblast differentiation and osteogenic cells from

\footnotetext{
${ }^{1}$ Department of Oral and Maxillofacial Surgery and Dental Research Center, Isfahan University of Medical Sciences, Isfahan, Iran.

${ }^{2}$ Department of Oral and Maxillofacial Pathology, School of Dentistry, Isfahan University of Medical Sciences, Isfahan, Iran.

${ }^{3}$ Department of Endodontics and Dental Research Center, Isfahan University of Medical Sciences, Isfahan, Iran.

${ }^{4}$ Dentist, Tehran, Iran.

${ }^{5}$ Department of Oral and Maxillofacial Surgery, Kermanshah University of Medical Sciences, Kermanshah, Iran.
} 
mesanchymal stem cells (Khazaei et al., 2014). In essence, resveratrol has anti-inflammatory properties and has the ability to inhibit inflammatory molecules. It this drug also has inhibitory effects on intrinsic inflammatory mediators such as tumor necrosis factor (TNF), IL-1, IL-6, IL-12 and interferons (Khazaei et al., 2014). It also elevates protein production by osteogenic cells. Reports indicated that resveratrol has accelerating effect on division of mesenchymal stem cells and differentiation of osteoblast and has positive outcomes overall in osteogenesis.

Evidence suggests that resveratrol may be beneficial and can be considered as supplemental treatment in socket and ridge preservation. Hence, the aim of the present study was to investigate the effect of systemic supplement of resveratrol for post-extraction alveolar socket preservations.

\section{MATERIAL AND METHOD}

In this study 30 Wistar rats (Pasteur Institute, Tehran, Iran) were selected using convenient sampling method. Samples were chosen due to inclusion criteria with improbable approach. The samples were 5 weeks old on average, and weighed 110 to $120 \mathrm{~g}$. Samples were treated with standard protocols, free access to water and food; they had access to the same number of light and dark hours. Rats were delivered to the laboratory few days before the study began. They were kept in cages with air filter. Temperatures of the cages were $70 \pm 5{ }^{\circ} \mathrm{F}$ and $20 \%$ humidity. A light and dark cycle of hours were arranged every 12 hours for the rats. The rats were divided to 2 groups randomly. Matching technique was used to divide study and control group with equal demographic distributions. The study was conducted with Oral and Maxillofacial surgeons for the surgical procedures. An oral and maxillofacial pathologist looked into pathologic samples and an epidemiologist was assigned to analyze the data gathered from results. All of the investigators were blinded of the groups.

In order to extract second molar teeth ketamine hydrochloride $10 \%(80 \mathrm{mg} / \mathrm{kg})$ and xylazine $(8 \mathrm{mg} / \mathrm{kg})$ were used for general anesthesia. During anesthesia, samples were monitored with their vital signs, breathing count and heartbeat. For extracting the teeth, custom made hemostat forceps were used. For bleeding control sterile gauze and cotton rolls were used.

For the next 28 days, mice were kept in the same condition as two groups, study group and control group. During these 28 days, one group was used as study group and the other as control group. The study group rats received ab- dominal injection of $20 \mathrm{mg} / \mathrm{kg}$ resveratrol (Sigma-Aldrich $®$, Germany) every day. Placebo injections were conducted in control group rats. Rats had standard diet during the experiment time of 28 days (Ali-Erdem et al., 2011). After 28 days of treatment, subjects were sacrificed and histological samples were collected from center second molar sockets.

Bone samples were decalcified in EDTA $10 \%$. Then 5 micron cuts were made through the samples and after preparation they were observed under light microscope. Digital images with $400 \mathrm{x}$ magnification were observed and evaluated for new bone formation, inflammation, necrosis, fibrosis, and foreign body reaction. Inflammation and fibrosis were graded as + (1-30\%), ++ (30-60\%) and +++ (60-100 $\%)$. Necrosis and foreign body reaction was graded with "YES" (as presence of necrosis and foreign body reaction) and "NO" (as no presence of necrosis and foreign body reaction). New bone formation was registered with percentile of presence of new bone; the newly formed trabecules were observed in several perspectives. The formation of trabecules was measured in a $30 \times 40$ grid surface with counting the grids with new bone formation (Shahriari et al., 2012).

Data were analyzed by SPSS 16 using Mann-Whitney $\mathrm{U}$ and Fisher Exact test. P-value less than 0.05 considered as significant level.

\section{RESULTS}

The mean bone formation in control group was 28.30 $\%$ and in study group treated with resveratrol was $45 \%$. There were significant statistical differences between control group and study group results due to new bone formation (Mann-Whitney U, P-value=0.037) (Table I and Fig. 1).

Inflammation was higher in control group in comparison with study group. Although the amount and the intensity of inflammation was not significantly different in control and study groups (Fisher Exact test, P-value=0.99). There was no evidence of dense and focal inflammatory response in neither of groups (Fig. 1). There was no significant difference between the groups in the term of fibrosis (Fisher Exact test, P-value=0.99) (Fig. 1). There were no detected necrotic foci in the group treated with resveratrol. However, in control group, 3 out of 15 samples showed sites of necrosis. Although statistical analysis showed no significant difference between study groups and sample groups (Fisher Exact test, P-value=0.224). Foreign body reaction was not detected in any of the control group samples and there were no significant difference between study groups and control groups (Fisher Exact test, P-value=0.224). 
Table I. New bone formation in studied groups

\begin{tabular}{lcccc}
\hline Groups & Number of Sample & Minimum & Maximum & Mean \pm SD \\
\hline Resveratrol & 15 & 18.00 & 82.00 & $45.00 \pm 2.3^{*}$ \\
Control & 15 & 14.00 & 44.00 & $28.30 \pm 1.0^{*}$
\end{tabular}

*Data are in percent, Mann-Whitney U, P-value $=0.037$; SD: standard deviation.
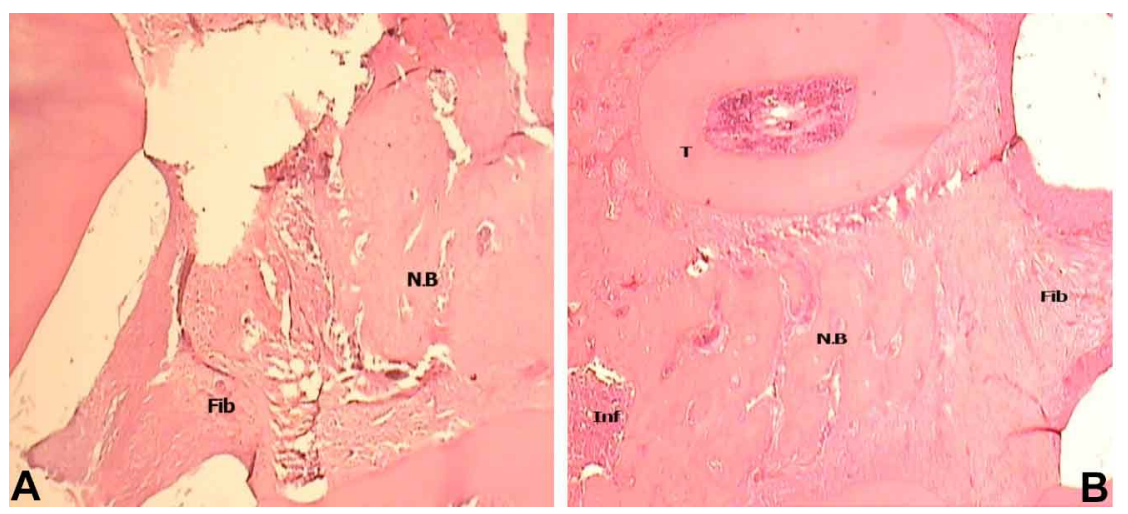

Fig. 1. New bone formation (N.B) (¥100); (a): Control, (b): Resveratrol. Inf: Inflammation, Fib: Fibrosis.

\section{DISCUSSION}

Results of the present study showed that resveratrol can be considered as supplement treatment for alveolar socket preservation.

Bone healing after surgical procedures is a process of regaining structure and function. The process of healing is based on osteoblasts' activity and osteogenic cell's differentiation and their migration patterns (Andrade et al., 2013). Studies suggested that 4 weeks is an appropriate time for cells initiate and progress in bone formation (Gerstenfeld et al., 2005; Ejiri et al., 2006). It is shown that aryl hydrocarbons can be strong inhibitors for osteoblast differentiation and can induce osteoclast activity. Resveratrol is a potent inhibitor of aryl hydrocarbon receptor and can stop the effects of its activation (Singh et al.). Moreover, resveratrol has antioxidant, anti-inflammatory, anti-aging effects that makes this herbal substance a positive effect on bone healing process (Cottart et al., 2010; Sánchez-Fidalgo et al., 2010).

The present study have shown that systemic application of resveratrol showed improvement of bone healing process with limited side effects. Some studies have reported that resveratrol can up-regulate translation of Bone Morphogenic Protein-2 (BMP-2), Bone Morphogenic Protein-7 (BMP-7) and OPN (Osteopontin). Up-regulating BMP gene production can have great impact on bone formation process. Although, it is shown that resveratrol could not release BMP-6 in the cell culture medium (Gruber et al., 2003; Su et al., 2007). Casarin et al. has investigated effects of resveratrol application on bone healing process and showed that resveratrol can accelerate production of osteoproteins in mice.

On the other hand, it has been reported that resveratrol up-regulates vitamin $\mathrm{D}$ receptors in bone marrow cells which will result in more osteoblastic differentiation and inhibition of osteoclastic activities (Boissy et al., 2005; Song et al., 2006; Kupisiewicz et al., 2010). This phenomenon can accelerate bone healing after surgery, tooth extraction and makes it suitable material for alveolar socket preservation. Dai et al. (2007) reported that resveratrol can accelerate human osteoblastic maturation and mesenchymal stem cell differentiation in human cells. In an in vitro study resveratrol has a dose dependent relationship with osteoblast maturation and differentiation. The presence of resveratrol can elevate osteogenic markers. This report indicated that mesenchymal stem cells and osteoblasts' reproduction was increased in the presence of resveratrol.

Resveratrol reduces secretion of inflammatory cytokines such as IL-8 that has a bone destructive effect. IL-8 is also a strong chemokine (chemo-attractant) for neutrophils to inflammation location. With the presence of more inflammatory cells, the destruction of present structures will be more significant. Studies have reported that IL-8 elevates in inflammatory periodontitis and periodontal treatments reduce its amount.

The present study was preclinical study of our future clinical trial to evaluate the side effect and histopathological effect of resveratrol. The randomization and blinding were done in the current study which is one of the strengths of this pilot study. Although the evidence supports the effectiveness of resveratrol on bone healing, more studies are require to evaluate its side effects, dosage, and time of application. There are limited animal and clinical studies about effects of this drug on healing bone defects. Therefore it seems necessary to conduct more studies and provide more significant data for backing up this hypothesis.

In conclusion, resveratrol can be considered as supplement drug for enhancing bone formation in alveolar socket preservation. 
HASHEMINIA, D.; RAZAVI, S. M.; NAZARI, H.; KHAZAEI, S.; SOLEIMANZADEH, P. \& NAZARI, H. Aumento de la formación ósea en el hueso alveolar de rata con suplemento sistémico con resveratrol. Int. J. Morphol., 36(2):391-394, 2018.

RESUMEN: El resveratrol en los medios de cultivo celular aumenta los marcadores osteoblásticos. Los resultados de estudios anteriores proporcionan evidencia de efectos positivos del resveratrol sobre la curación ósea y la producción ósea. En este estudio preclínico, investigamos la curación ósea en ratas mediante la aplicación sistémica de resveratrol. Se dividieron 30 ratas macho Wistar en dos grupos (estudio y control). Inicialmente se extrajeron los segundos molares maxilares de las ratas y los animales se mantuvieron en el laboratorio durante los siguientes 28 días. El grupo de estudio recibió todos los días resveratrol $20 \mathrm{mg} / \mathrm{kg}$ por inyección abdominal . El grupo control recibió placebo de la misma manera que el grupo estudio. Las ratas fueron sacrificadas después de 28 días y se recogieron muestras de hueso del centro del segundo molar maxilar. Las muestras se evaluaron histológicamente para la formación de hueso nuevo, inflamación, necrosis, fibrosis y reacción de cuerpo extraño. La media de formación de hueso nuevo en el grupo control $(28,30 \%)$ y en el grupo estudio ( $45 \%)$ fueron estadísticamente significativas ( $\mathrm{P}=0,014)$. No hubo diferencias significativas en la inflamación, fibrosis, necrosis y reacción al cuerpo extraño $(\mathrm{P}>0,05)$. El resveratrol tiene efectos positivos sobre la curación de los huesos, pero aún es necesario realizar más pruebas de estudios clínicos, como también en animales.

PALABRAS CLAVE: Resveratrol; Aumento de cresta alveolar; Formación de hueso; Osteoblastos; Osteoclastos

\section{REFERENCES}

Ali-Erdem, M.; Burak-Cankaya, A.; Cemil-Isler, S.; Demircan, S.; Soluk, M.; Kasapoglu, C. \& Korhan-Oral, C. Extraction socket healing in rats treated with bisphosphonate: animal model for bisphosphonate related osteonecrosis of jaws in multiple myeloma patients. Med. Oral Patol. Oral Cir. Bucal, 16(7):e879-83, 2011.

Andrade, A. R.; Sant'Ana, D. C.; Mendes, J. A. Jr.; Moreira, M.; Pires, G. C.; Santos, M. P.; Fernandes, G. J.; Nakagaki, W. R.; Garcia, J. A.; Lima, C. C. \& Soares, E. A. Effects of cigarette smoke inhalation and coffee consumption on bone formation and osseous integration of hydroxyapatite implant. Braz. J. Biol., 73(1):173-7, 2013.

Boissy, P.; Andersen, T. L.; Abdallah, B. M.; Kassem, M.; Plesner, T. \& Delaissé, J. M. Resveratrol inhibits myeloma cell growth, prevents osteoclast formation, and promotes osteoblast differentiation. Cancer Res., 65(21):9943-52, 2005

Casarin, R. C.; Casati, M. Z.; Pimentel, S. P.; Cirano, F. R.; Algayer, M.; Pires, P. R.; Ghiraldini, B.; Duarte, P. M. \& Ribeiro, F. V. Resveratrol improves bone repair by modulation of bone morphogenetic proteins and osteopontin gene expression in rats. Int. J. Oral Maxillofac. Surg., 43(7):900-6, 2014.

Casati, M. Z.; Algayer, C.; Cardoso da Cruz, G.; Ribeiro, F. V.; Casarin, R. C.; Pimentel, S. P. \& Cirano, F. R. Resveratrol decreases periodontal breakdown and modulates local levels of cytokines during periodontitis in rats. J. Periodontol., 84(10):e58-64, 2013.

Cottart, C. H.; Nivet-Antoine, V.; Laguillier-Morizot, C. \& Beaudeux, J. L. Resveratrol bioavailability and toxicity in humans. Mol. Nutr. Food Res., 54(1):7-16, 2010.

Dai, Z.; Li, Y.; Quarles, L. D.; Song, T.; Pan, W.; Zhou, H. \& Xiao, Z. Resveratrol enhances proliferation and osteoblastic differentiation in human mesenchymal stem cells via ER-dependent ERK1/2 activation. Phytomedicine, 14(12):806-14, 2007.

Ejiri, S.; Toyooka, E.; Tanaka, M.; Anwar, R. B. \& Kohno, S. Histological and histomorphometrical changes in rat alveolar bone following antagonistic tooth extraction and/or ovariectomy. Arch. Oral Biol., 51(11):941-50, 2006.

Gerstenfeld, L. C.; Wronski, T. J.; Hollinger, J. O. \& Einhorn, T. A. Application of histomorphometric methods to the study of bone repair. J. Bone Miner. Res., 20(10):1715-22, 2005.

Gruber, R.; Graninger, W.; Bobacz, K.; Watzek, G. \& Erlacher, L. BMP-6induced osteogenic differentiation of mesenchymal cell lines is not modulated by sex steroids and resveratrol. Cytokine, 23(4-5):133-7, 2003.

Khazaei, S.; Firouzei, M. S.; Afghari, P. \& Khazaei, M. Resveratrol may improve osseointegration of dental implants in type 2 diabetes mellitus patients. J. Res. Med. Sci., 19(1):81, 2014.

Khazaei, S.; Khazaei, M.; Kazemi, S. \& Yaghini, J. Resveratrol as a supplemental treatment for periodontitis. Dent. Res. J. (Isfahan), 9(5):6557, 2012.

Kupisiewicz, K.; Boissy, P.; Abdallah, B. M.; Hansen, F. D.; Erben, R. G.; Savouret, J. F.; Søe, K.; Andersen, T. L.; Plesner, T. \& Delaisse, J. M. Potential of resveratrol analogues as antagonists of osteoclasts and promoters of osteoblasts. Calcif. Tissue Int., 87(5):437-49, 2010.

Liu, Z. P.; Song, Y.; Liu, Z. Q. \& Zhang, X. P. Preventive effect of transresveratrol on hypertension-induced cardiac hypertrophy in partially nephrectomized rats. Wei Sheng Yan Jiu, 34(6):756-8, 2005.

Pang, E. K.; Im, S. U.; Kim, C. S.; Choi, S. H.; Chai, J. K.; Kim, C. K.; Han, S. B. \& Cho, K. S. Effect of recombinant human bone morphogenetic protein-4 dose on bone formation in a rat calvarial defect model. $J$. Periodontol., 75(10):1364-70, 2004.

Sánchez-Fidalgo, S.; Cárdeno, A.; Villegas, I.; Talero, E. \& de la Lastra, C. A. Dietary supplementation of resveratrol attenuates chronic colonic inflammation in mice. Eur. J. Pharmacol., 633(1-3):78-84, 2010.

Shahriari, S.; Houshmand, B.; Razavian, H.; Khazaei, S. \& Abbas, F. M. Effect of the combination of enamel matrix derivatives and deproteinized bovine bone materials on bone formation in rabbits' calvarial defects. Dent. Res. J. (Isfahan), 9(4):422-6, 2012.

Singh, S. U.; Casper, R. F.; Fritz, P. C.; Sukhu, B.; Ganss, B.; Girard, B. Jr.; Savouret, J. F. \& Tenenbaum, H. C. Inhibition of dioxin effects on bone formation in vitro by a newly described aryl hydrocarbon receptor antagonist, resveratrol. J. Endocrinol., 167(1):183-95, 2000.

Song, L. H.; Pan, W.; Yu, Y. H.; Quarles, L. D.; Zhou, H. H. \& Xiao, Z. S. Resveratrol prevents CsA inhibition of proliferation and osteoblastic differentiation of mouse bone marrow-derived mesenchymal stem cells through an ER/NO/cGMP pathway. Toxicol. In Vitro, 20(6):915-22, 2006.

Su, J. L.; Yang, C. Y.; Zhao, M.; Kuo, M. L. \& Yen, M. L. Forkhead proteins are critical for bone morphogenetic protein-2 regulation and anti-tumor activity of resveratrol. J. Biol. Chem., 282(27):19385-98, 2007.

Zhou, H.; Shang, L.; Li, X.; Zhang, X.; Gao, G.; Guo, C.; Chen, B.; Liu, Q.; Gong, Y. \& Shao, C. Resveratrol augments the canonical Wnt signaling pathway in promoting osteoblastic differentiation of multipotent mesenchymal cells. Exp. Cell. Res., 315(17):2953-62, 2009.

Corresponding author:

Hamed Nazari

Department of Oral and Maxillofacial Surgery and Dental Research Center

Isfahan University of Medical Sciences

Isfahan

IRAN

Email: nazari.hamed67@yahoo.com

Received: 27-06-2017

Accepted: 07-02-2018 